\title{
Stabilitas Daging Ayam dengan Pelapisan Edible Coating Berbahan Kasein-Kitosan Selama Penyimpanan
}

\section{Stability of Chicken Meat with Casein- Chitosan Edible Coating During Storage}

\author{
Mulia Winirsya Apriliyani ${ }^{\# 1}$, Premy Puspitawati Rahayu ${ }^{* 2}$, Abdul Manab ${ }^{\# 3}$ \\ ${ }^{\#}$ Jurusan Peternakan, Minat Teknlogi Hasil Ternak Universitas Brawijaya \\ Jalan Veteran, Malang \\ ${ }^{1}$ muliaapriliyanieub.ac.id \\ 2premypuspita@ub.ac.id \\ 3manabub2@yahoo.com
}

\begin{abstract}
The purpose of this study were to determine the effect of the stability of the use of casein edible coatings and chitosan on chicken meat with different storage times in terms of peroxide numbers, iodine numbers, antioxidant activity, bacterial counts, S. aureus, E. coli, and Salmonella sp. The treatment of chicken meat coated with edible coating temperature of $\pm 8{ }^{\circ} \mathrm{C}$ with a difference of shelf life for 1 day, 4 days, 10 days, 12 days, 14 days and 21 days. Research data will be analyzed using Analysis of Variance and followed by Duncan's Multiple Range Test (UJBD) if there are significant differences. The results showed that chicken meat coated with casein chitosan edible coating with long storage treatment gave a very significant effect $(P<0.01)$ on the value of iodine numbers, peroxide numbers, and antioxidant activity, ALT and S. aureus. Casein and chitosan edible coating can provide stability in a certain shelf life at a temperature of $8^{\circ} \mathrm{C}$.
\end{abstract}

Keywords — edible coating, casein chitosan, stability, storage.

\section{PENDAhuluan}

Daging ayam yang dijual dipasar tradisional maupun di pasar modern memiliki daya simpan yang terbatas. Daya tahan suatu daging ayam dipengaruhi oleh komposisi bahan makanan tersebut. Daya tahan daging ayam yang relatif singkat disebabkan teroksidasinya lemak/lipid yang mengakibatkan bau tengik. Proses ketengikan terjadi karena adanya serangan oksigen pada lemak tidak jenuh yang menyebabkan oksidasi lemak. Mutu daging ayam dapat menurun seiring dengan lamanya penyimpanan, baik secara fisik, mikrobiologi maupun organoleptik. Daging broiler yang disimpan pada suhu $0-4{ }^{\circ} \mathrm{C}$ menurut Sangadji, Julianto dan Ridjal (2019) dapat bertahan 3 hari, sedangkan penyimpanan pada suhu sekitar $8{ }^{\circ} \mathrm{C}$ hanya dapat bertahan dua hari. Pada penyajian daging ayam perlu dibuat perencanaan terpadu yang dapat mempertahankan kualitas sehingga umur simpan lebih panjang. Menurut penelitian [1] Apriliyani et al., 2020 bahwa penambahan catechin ke lapisan yang dapat dimakan casein-chitosan hanya meningkatkan kapasitas antioksidannya tanpa meningkatkan aktivitas antimikroba bila diterapkan pada dada ayam mentah selama dipercepat uji penyimpanan pada $7^{\circ} \mathrm{C}$.

Edible coating adalah lapisan tipis yang dapat diaplikasikan sebagai cairan dengan viskositas yang bervariasi pada permukaan produk pangan dengan cara penyemprotan, pencelupan, penyikatan, atau metode lainnya [2] Khare et al., 2016. Bahan utama yang digunakan dalam penelitian ini yaitu kasein dan kitosan. Kasein sebagai protein memiliki sifat sukar terpecah oleh panas yang tinggi sehingga baik digunakan sebagai bahan dasar pembuatan edible film [3] Maruddin, Ako, Hajrawati, dan Taufik, 2016), sedangkan kitosan dapat membentuk lapisan semi-permeabel dan bisa digunakan untuk meningkatkan umur simpan produk segar dan sebagai cadangan makanan dengan nilai aktivitas air yang lebih tinggi [4] Bourtoom, 2008. Kasein- 
kitosan memiliki efektivitas antimikroba sehingga dapat memperpanjang masa simpan daging. Kaseinkitosan yang digunakan dalam edible coating akan menambah komponen aktif [5] Moreira et al., 2011. Berdasarkan uraian diatas dilakukan penelitian untuk mengetahui stabilitas bilangan peroksida, angka iod, aktivitas antioksidan, jumlah bakteri, S. aureus, E. coli, dan Salmonella sp. pada daging ayam yang dilapisi edible coating kasein-kitosan selama penyimpanan.

\section{METODOLOGI}

A. Pembuatan dan pengaplikasian Edible Coating Kasein Kitosan.

Bahan-bahan yang digunakan dalam penelitian ini, untuk pembuatan edible coating yaitu kasein (Merck) dan kitosan (Makmur Sejati), gliserol (Merck), aquades dan asam asetat 2\%, kemudian diaplikasikan pada daging bagian dada.

Proses pembuatan edible coating dilakukan dengan melarutkan kasein dengan aquades sebanyak $1 \mathrm{~g} / 50 \mathrm{ml}$ aquades dan melarutkan kitosan menggunakan asam asetat $2 \%$ sebanyak $1 \mathrm{~g} / 50 \mathrm{ml}$. Larutan kasein dan larutan kitosan selanjutnya dipanaskan masing-masing selama 30 menit dengan suhu $50^{\circ} \mathrm{C}$, selama proses pemanasan ditambahkan gliserol 0,28\% pada masing-masing larutan. Larutan edible coating kasein kitosan yang telah siap diaplikasikan pada daging ayam dengan cara oles. Perlakuan daging ayam yang dilapisi edible coating suhu $\pm 8^{0} \mathrm{C}$ dengan perbedaan masa simpan selama 1 hari, 4 hari, 10 hari, 12 hari, 14 hari, dan 21 hari.

\section{B. Metode}

Metode penelitian yang digunakan adalah metode percobaan laboratorium yang menggunakan Rancangan Acak Lengkap (RAL) dengan 5 perlakuan dan 4 kali ulangan.

\section{Angka Iod}

Pengujian angka iod pada penelitian ini menggunakan metode Apriyantono dkk. (1989). Sampel sebanyak 0,1-0,5 g dimasukkan (tergantung derajat ketidakjenuhannya) ke dalam Erlenmeyer tertutup, kemudian ditambahkan $10 \mathrm{ml}$ kloroform untuk melarutkan sampel, ditambahkan $25 \mathrm{ml}$ pereaksi Hanus dan dibiarkan 1 jam di tempat gelap, sambal sekali-kali dikocok (sesudah reaksi sempurna diharapkan terdapat banyak kelebihan Iod, sedikitnya 60\%). Selanjutnya, ditambahkan dan dikocok $10 \mathrm{ml}$ larutan KI $15 \%$, dititrasi dengan larutan standar $\mathrm{Na}_{2} \mathrm{~S}_{2} \mathrm{O}_{3} \quad 0,1 \mathrm{~N}$ sampai warna kuning Iod hamper hilang, ditambahkan $2 \mathrm{ml}$ larutan pati $1 \%$ sebagai indikator, dilanjutkan titrasi. Jika warna biru hamper hilang, titrasi dihentikan. Erlenmeyer digoyang-goyang dengan cepat sehingga Iod yang masih tinggal dalam kloroform akan pindah ke larutan KI, kemudian dilanjutkan titrasi sampai titik akhir tercapai (sampai warna biru hilang), terakhir membuat larutan blanko. Penetapan Angka Iod seperti berikut:

Angka Iod $=\underline{\text { (titer blanko-titer sampel) } \times \text { N.Na2S2O3 } \times 12,69}$ Berat sampel dalam gram

\section{Bilangan Peroksida}

Pengujian bilangan peroksida pada penelitian ini menggunakan metode [6] Apriyantono dkk. (1989). Sampel sebanyak $5 \mathrm{~g}$ dimasukkan ke dalam Erlenmeyer $250 \mathrm{ml}$, kemudian ditambahkan $30 \mathrm{ml}$ pelarut asetat dan kloroform (2:10), ditambahkan 0,5 $\mathrm{ml}$ larutan potassium iodide jenuh, didiamkan selama 2 menit di ruang gelap sambal digoyang dan menambahkan $30 \mathrm{ml}$ aquades. Kelebihan Iod dititrasi dengan larutan sodium tiosulfat $0,1 \mathrm{~N}$ atau $0,01 \mathrm{~N}$ (tergantung dari banyaknya jumlah Iod yang dibebaskan. Dengan cara yang sama membuat larutan blanko. Penetapan bilangan peroksida seperti berikut:

Bilangan Peroksida $(\mathrm{ml} . \mathrm{eq} / \mathrm{kg})=\underline{\mathrm{A} \times \mathrm{N} \times 1000}$

G

Keterangan:

$\mathrm{A}=\mathrm{ml}$ sodium tiosulfat yang dipakai sampel-ml sodium tiosulfat yang dipakai penetapan blanko

$\mathrm{N}=$ Normalitas sodium tiosulfat

$\mathrm{G}=$ Berat contoh minyak/lemak (gram)

\section{E. Aktivitas antioksidan}

Pengujian angka iod pada penelitian ini menggunakan metode DPPH [7] Andayani et al., 2008. Sebanyak $5 \mathrm{mg}$ sampel dilarutkan dengan 10 $\mathrm{ml}$ metanol dalam labu ukur, maka didapatkan konsentrasi $1 \mathrm{mg} / \mathrm{ml}$. Selanjutnya dilakukan pengenceran dengan menambahkan metanol sehingga diperoleh sampel dengan konsentrasi (10, 30, 50, 70, $90 \mathrm{~g} / \mathrm{ml})$. Untuk penentuan aktivitas antioksidan masing-masing konsentrasi dipipet sebanyak 0,2 ml larutan sampel dengan pipet mikro dan masukan ke dalam botol vial. Lalu tambahkan $3,8 \quad \mathrm{ml}$ larutan DPPH $50 \mu \mathrm{M}$. Campuran dihomogenkan dan dibiarkan selama 30 menit ditempat gelap, serapan diukur dengan spektrofotometer UV-Vis pada panjang gelombang $515 \mathrm{~nm}$.

\section{F. Angka Lempeng Total}

Pengujian Angka Lempeng Total pada penelitian ini menggunakan metode [8] Turkoglu et al., (2003). Sebanyak $5 \mathrm{~g}$ sampel dihaluskan dan dimasukkan dalam erlenmayer tang telah berisi $45 \mathrm{ml}$ larutan pepton $0,1 \%$ dan diaduk-aduk hingga homogen (pengenceran $10^{-1}$ ). Selajutnya menyiapkan seri pengenceran $10^{-2}$ sampai dengan $10^{-4}$ dengan cara pipet sebanyak $1 \mathrm{ml}$ dari larutan pengencer $10^{-1} \mathrm{ke}$ dalam tabung reaksi yang telah berisi $9 \mathrm{ml}$ larutan pepton $0,1 \%$ (pengencer $10^{-2}$ ) dan sama seterusnya hingga pengencer $10^{-4}$. Menuangkan media PCA sebanyak kurang lebih $15 \mathrm{ml}$ secara merata hingga 
Mulia Winirsya Apriliyani, Premy Puspitawati Rahayu, Abdul Manab. Stabilitas Daging Ayam dengan

Pelapisan Edible Coating Berbahan Kasein-Kitosan Selama Penyimpanan

menutupi permukaan dalam cawan petri, kemudian pipet sebanyak $1 \mathrm{ml}$ larutan pengencer $10^{-4}$ dan tuangkan ke dalam cawan petri secara merata, dan dibiarkan hingga membeku, lalu cawan petri dibalik, demikian seterusnya dengan cara yang sama untuk pengenceran $10^{-5}$ dan $10^{-6}$ (metode pour plate). Sampel diinkubasi pada suhu $37^{\circ} \mathrm{C}$ selama 48 jam, kemudian melakukan perhitungan jumlah koloni bakteri yang tumbuh dengan colony counter.

\section{G. Staphylococcus Aureus}

Pengujian $S$. aureus pada penelitian ini menggunakan prosedur uji Staphylococcus aureus [9] AOAC International, 1995. Sampel sebanyak $5 \mathrm{~g}$ dan dihancurkan sampai halus dan homogen. Sampel yang telah dihaluskan dimasukkan dalam Erlenmeyer yang telah berisi $45 \mathrm{ml}$ larutan pepton $0,1 \%$ dan diaduk-aduk hingga homogen (pengenceran $10^{-1}$ ). Disiapkan seri pengenceran dengan cara dipipet sebanyak $1 \mathrm{ml}$ dari larutan pengenceran $10^{-1}$ ke dalam tabung reaksi yang telah berisi $9 \mathrm{ml}$ larutan pepton $0,1 \%$ (pengenceran $10^{-2}$ ) Tuangkan media BPA sebanyak $\pm 15 \mathrm{ml}$ secara merata hingga menutupi permukaan bagian dalam cawan petri dan dibiarkan hingga membeku, lalu dipipet sebanyak $0,1 \mathrm{ml}$ larutan pengenceran $10^{-1}$ dan dituangkan ke atas permukaan agar/media yang btelah membeku secara merata, dibiarkan membeku, lalu cawan petri dibalik, demikian juga dengan cara yang sama untuk pengenceran $10^{-2}$ (metode spread plate). Diinkubasi pada inkubator dengan suhu $37^{\circ} \mathrm{C}$ selama 48 jam, kemudian perhitungan jumlah koloni bakteri yang tumbuh dengan colony counter.

\section{H. Escherichia coli}

Pengujian E. coli pada penelitian ini menggunakan prosedur uji (Hajrawati dkk., 2016). Suspensi pengenceran $10^{-1}, 10^{-2}$, dan $10^{-3}$ digunakan untuk menentukan jumlah E. coli. Sebanyak $1 \mathrm{~mL}$ dari tiap-tiap pengenceran dimasukkan ke dalam cawan petri steril yang berbeda secara duplo. Kemudian cawan petri tersebut dituang media Eosin Methylene Blue Agar [10] EMBA, Himedia M022500G steril. Setelah media memadat, diinkubasi dengan posisi terbalik terbalik selama 24-48 jam pada suhu $37^{\circ}$ C. Setelah 24-48 jam, dilakukan penghitungan koloni E. coli.

\section{Salmonella sp}

Pengujian Salmonella sp. pada penelitian ini menggunakan Prosedur Uji Salmonella sp. [11] Sartika dkk., 2016. Sampel daging ayam ditimbang $1 \mathrm{~g}$ dan dihomogenkan dalam $10 \mathrm{ml}$ aquades steril. Sampel diencerkan menggunakan BPW steril pada pengenceran $10^{-1}$ sampai dengan $10^{-9}$. Masingmasing hasil pengenceran diambil sebanyak $1 \mathrm{ml}$ sampel dan dituang ke dalam media XLD agar dalam cawan petri steril lalu dihomogenkan. Sampel diinkubasi pada incubator pada suhu $37{ }^{\circ} \mathrm{C}$ selama 24 jam. Koloni bakteri yang tumbuh diamati dan dihitung menggunakan colony counter. Penetapan hasil uji Salmonella sp. seperti berikut:

Jumlah koloni $=$ jumlah koloni pada cawan $\times \frac{1}{\text { faktor pengencer }}$

Data dianalisis menggunakan analisis ragam, apabila ada perbedaan yang nyata atau sangat nyata maka dianalisis lanjut dengan menggunakan Uji Jarak Berganda Duncan (UJBD).

\section{III.HASIL DAN PEMBAHASAN}

\section{A. Angka Iod}

Hasil analisis statistik menunjukkan pelakuan penyimpanan memberikan pengaruh yang sangat nyata $(\mathrm{P}<0,01)$ terhadap angka iod daging ayam yang dilapisi edible coating kasein-kitosan. Pada Tabel 1 menunjukkan semakin lama penyimpanan maka terjadi peningkatan angka iod yang dihasilkan karena proses oksidasi lemak pada daging ayam. Banyaknya angka iod bahwa antioksidan akan menghambat dan menginaktivasi radikal bebas agar tidak merusak asam lemak jenuh pada lipid. Menurut [12] Ketaren 2005, besarnya jumlah Iod yang diserap menunjukkan banyaknya ikatan rangkap atau tidak jenuh. [13] Gheisari 2011 menyatakan bahwa daging ayam memiliki angka iod $80,67 \mathrm{~g} \mathrm{I}_{2} / 100 \mathrm{~g}$,

\section{B. Bilangan Peroksida}

Hasil analisis statistik menunjukkan pelakuan penyimpanan memberikan pengaruh yang sangat nyata $(\mathrm{P}<0,01)$ terhadap bilangan peroksida daging ayam yang dilapisi edible coating kasein-kitosan. Pada Tabel 1 menunjukkan bilangan peroksida daging ayam yang dilapisi edible coating kaseinkitosan semakin tinggi pada penyimpanan 21 hari, hal tersebut menunjukkan peningkatan bilangan peroksida yang dihasilkan akibat proses oksidasi lemak atau minyak yang utama adalah karena peristiwa oksidasi dan hidrolitik, baik enzimatik maupun non-enzimatik.

Kenaikan angka peroksida terjadi karena minyak mengalami reaksi dengan oksigen pada ikatan rangkap dan terjadi reaksi berantai yang terusmenerus menyediakan radikal bebas yang menghasilkan peroksida [14] Gunawan dkk., 2003. Kitosan mampu memperlambat oksidasi lipid mayones pada suhu yang lebih tinggi [15] García,et al.,2014. Bilangan peroksida yang lebih tinggi pada daging ayam yang disimpan lebih 14 hari akan lebih mudah teroksidasi secara lanjut, seperti pada penyimpanan 21 hari bilangan peroksida mencapai $8,22 \pm 0,34 \mathrm{~m} . \mathrm{eq} / \mathrm{kg}$. Angka peroksida pada suatu produk makanan yang dapat ditoleransi pada kisaran 
10-20 m.eq $/ \mathrm{kg}$ [16] Abdellah et al., 2012; BSN, 2013. Semakin besar kadar angka peroksida suatu asam lemak, maka semakin besar tingkat oksidasinya. Akan tetapi, kadar angka peroksida tidak dapat dijadikan acuan tingkat oksidasi dari asam lemak, karena angka peroksida mudah terdegradasi pada oksidasi tahap akhir atau terminasi [17] Rauf, 2015.

\section{Aktivitas antioksidan}

Hasil analisis statistik menunjukkan pelakuan penyimpanan memberikan pengaruh yang sangat nyata $(\mathrm{P}<0,01)$ terhadap aktivitas antioksidan $\mathrm{IC}_{50}$ DPPH daging ayam yang dilapisi edible coating kasein-kitosan. Penambahan antioksidan dapat berpengaruh pada laju oksidasi. Semakin lama penyimpanan menghasilkan nilai yang rendah maka aktivitas antioksidannya kategori sangat kuat.

Nilai $\mathrm{IC}_{50}$ dari hidrolisat dari $\alpha \mathrm{s} 2$-casein dan $\kappa$ casein masing-masing adalah 41,8 dan 9,97 $\mu \mathrm{g}$ protein/ml [18] Lopez'-Exposito' et al., 2007. Pengaruh jumlah konsentrasi antioksidan pada laju oksidasi tergantung pada struktur antioksidan dan kondisi daging ayam yang dilapisi edible coating kasein-kitosan. Menurut [19] Rajaram dan Rasool 2010, pada kondisi hidrofobik, protein hidrolisat dan peptide akana meningkatkan kelarutan dalam lemak, sehingga aktivitas antioksidan akan meningkat. Aktivitas antioksidan dari histidine yang mengandung peptide memiliki kemampuan pengkhelat dan perangkap radikal lemak.

TABEL 1.

ANGKA IOD, BILANGAN PEROKSIDA, DAN AKTIVITAS ANTIOKSIDAN PADA DAGING AYAM YANG DILAPISI EDIBLE COATING KASEIN-

\begin{tabular}{|c|c|c|c|}
\hline $\begin{array}{c}\text { Perlakuan } \\
\text { (hari) }\end{array}$ & $\begin{array}{c}\text { Angka Iod } \\
(\mathrm{g} / 100 \mathrm{~g})\end{array}$ & $\begin{array}{c}\text { Bil. Peroksida } \\
(\mathrm{m} . \mathrm{eq} / \mathrm{kg})\end{array}$ & $\begin{array}{c}\text { IC50 DPPH } \\
(\mu \mathrm{g} / \mathrm{mL})\end{array}$ \\
\hline 1 & $6,038 \pm 0,691^{\mathrm{a}}$ & $0,77 \pm 0,10^{\mathrm{a}}$ & $54,51 \pm 2,10^{\mathrm{e}}$ \\
\hline 4 & $6,425 \pm 0,674^{\mathrm{a}}$ & $0,90 \pm 0,08^{\mathrm{a}}$ & $52,74 \pm 2,03^{\mathrm{e}}$ \\
\hline 10 & $7,388 \pm 0,554^{\mathrm{b}}$ & $1,15 \pm 0,13^{\mathrm{a}}$ & $50,54 \pm 2,00^{\mathrm{de}}$ \\
\hline 12 & $9,013 \pm 0,539^{c}$ & $3,15 \pm 0,26^{\mathrm{bc}}$ & $39,01 \pm 2,00^{\mathrm{c}}$ \\
\hline 14 & $10,925 \pm 0,411^{\mathrm{d}}$ & $4,22 \pm 0,34^{\mathrm{c}}$ & $34,17 \pm 1,97^{\mathrm{b}}$ \\
\hline 21 & $13,075 \pm 0,558^{\mathrm{e}}$ & $8,22 \pm 0,34^{\mathrm{d}}$ & $17,84 \pm 1,92^{\mathrm{a}}$ \\
\hline
\end{tabular}

Keterangan : Perlakuan memberikan pengaruh yang sangat nyata $(\mathrm{P}<0,01)$ terhadap nilai Angka Iod, Bilangan peroksida, dan Aktivitas antioksidan

Pelapis yang ditambahkan kitosan bertindak sebagai penghalang yang sangat baik untuk permeabilitas oksigen, sekali mereka diterapkan langsung di atas permukaan daging, memperlambat difusi oksigen [20] Nowzari et al., 2013. Aktivitas antioksidan dan penurunan permeabilitas oksigen telah diamati ketika film kitosan dimasukkan ke dalam produk daging [21] Gounlü and Koyun, 2013.th

Mekanisme antioksidan kitosan sebagai gugus amino primer akan membentuk fluorosfer stabil dengan aldehida lalu mudah menguap yang berasal dari pemecahan lemak selama oksidasi. Kelasi ion logam dianggap sebagai antioksidan alami (bagi kitosan) yang potensial untuk menstabilkan makanan yang mengandung lipid memperpanjang umur simpan [22] Mohan et al., 2012. Selain itu, mekanisme antioksidan kitosan dapat melalui aksi chelate dari logam ion dan atau kombinasi dengan lipid [23] López-Caballero et al., 2005, memiliki lapisan kitosan dan film telah dikenal sebagai penghalang yang baik untuk perembesan oksigen [24] Sathivel et al., 2007.

\section{Kualitas Mikrobiologi}

Hasil analisis statistik menunjukkan pelakuan penyimpanan memberikan pengaruh yang sangat nyata $(\mathrm{P}<0,01)$ terhadap ALT dan $S$. aureus.
Berdasarkan hasil penelitian pada Tabel 2 menunjukkan penyimpanan hari ke-12 sudah melebihi jumlah maksimal untuk ALT, E. coli, dan Salmonella sp. yang tertera dalam SNI 7388:2009. Menurut SNI 7388:2009 dijelaskan jumlah maksimal kandungan TPC yaitu $1 \times 10^{6} \mathrm{cfu} / \mathrm{g}$., Escherichia coli 1 x $10^{1} \mathrm{cfu} / \mathrm{g}$, dan Salmonella Sp. negatif/25gram. Kemampuan kasein dan kitosan sebagai bahan edible coating pada daging ayam dengan penyimpanan suhu $8^{\circ} \mathrm{C}$ tercapai pada hari ke- 10 .

Kitosan sebagai bahan pelapis menunjukkan antibakteri yang efektif dalam produk daging kering. Aktivitas antibakteri kitosan telah dijelaskan oleh sifat kationiknya yang memungkinkan interaksi elektrostatik antara muatan positif pada $\mathrm{NH}_{3}$ kelompok monomer glukosamin dalam molekul kitosan dan muatan negatif membran sel mikroba yang mengarah ke kebocoran konstituen intraseluler [25] Duan et al., 2010; Nouri et al., 2017; Verlee et al., 2017.

Mekanisme antimikroba kitosan dengan perubahan permukaan sel jamur atau bakteri yang menyebabkan permeabilisasi dan kebocoran bahan intraseluler yang mengakibatkan kematian sel, terutama melalui interaksi elektrostatik [26] Verlee, Mincke, \& Stevens, 2017. Kitosan berikatan secara non-kovalen dengan asam teichoic dari lapisan peptidoglikan bakteri Gram-positif, sedangkan pada 
Mulia Winirsya Apriliyani, Premy Puspitawati Rahayu, Abdul Manab. Stabilitas Daging Ayam dengan

Pelapisan Edible Coating Berbahan Kasein-Kitosan Selama Penyimpanan

bakteri Gram-negatif dapat bertindak sebagai chelator kation (nutrisi penting bagi sel) yang mengganggu integritas dinding sel atau melalui interaksi elektrostatik dengan bagian anionik dari lipopolysaccharide di membran luar [27] Nouri et al., 2017; Verlee et al., 2017.

TABEL 2.

ALT, S. AUREUS, E.COLI DAN SALMONELLA SP. PADA DAGING AYAM YANG DILAPISI EDIBLE COATING KASEIN-KITOSAN

\begin{tabular}{|c|c|c|c|c|}
\hline \multirow{2}{*}{$\begin{array}{l}\text { Perlakuan } \\
\text { (hari) }\end{array}$} & ALT & S. aureus & \multirow{2}{*}{$\begin{array}{l}\text { E. coli } \\
(\mathrm{APM} / \mathrm{g})\end{array}$} & \multirow[t]{2}{*}{ Salmonella sp. } \\
\hline & \multicolumn{2}{|l|}{$(\mathrm{cfu} / \mathrm{g})$} & & \\
\hline 1 & $3,02 \times 10^{3} \pm 0,04^{\mathrm{a}}$ & $0,075 \pm 0,96^{\mathrm{a}}$ & $<3,6$ & Negatif \\
\hline 4 & $3,15 \times 10^{3} \pm 0,03^{b}$ & $1,88 \times 10^{1} \pm 1,49^{b}$ & 3 & Negatif \\
\hline 10 & $3,04 \times 10^{4} \pm 0,05^{\mathrm{a}}$ & $5,75 \times 10^{1} \pm 2,84^{c}$ & 3,6 & Negatif \\
\hline 12 & $3,20 \times 10^{6} \pm 0,03^{\mathrm{b}}$ & $2,75 \times 10^{2} \pm 2,84^{\mathrm{d}}$ & 9,2 & Positif \\
\hline 14 & $3,13 \times 10^{7} \pm 0,04^{\mathrm{b}}$ & $3,47 \times 10^{2} \pm 2.84^{\mathrm{e}}$ & 21 & Positif \\
\hline 21 & $3,17 \times 10^{7} \pm 0,03^{b}$ & $5,27 \times 10^{2} \pm 2.84^{\mathrm{f}}$ & 35 & Positif \\
\hline
\end{tabular}

Keterangan : Perlakuan memberikan pengaruh yang sangat nyata $(\mathrm{P}<0,01)$ terhadap nilai ALT dan $S$. aureus

Susu peptida bioaktif (dari kasein dan whey) dapat memiliki aktivitas antibakteri karena interaksinya antara peptida dan membran bakteri yang kemudian diikuti oleh kerusakan membran, gangguan fisiologis membran seperti biosintesis dinding sel, pembelahan sel atau translokasi membran untuk berinteraksi dengan sitoplasma. Sel target umumnya diasumsikan sebagai kutub positif peptida berinteraksi dengan kutub negatif lipid pada permukaan luar atau membran sitoplasma, kemudian peptida disisipkan dengan orientasi posisi paralel pada lapisan ganda, ke dalam membran sitoplasma yang kemudian menghasilkan pelepasan lipid [28] Fjell et al., 2012. K-kasein hidrolisat ditemukan memiliki efektivitas tertinggi setelah 2 jam (aktivitas melawan E. coli) [29] Lopez'-Exposito' et al., 2007.

\section{IV.KESIMPULAN}

Dari hasi penelitian dapat disimpulkan bahwa perlakuan daging ayam yang dilapisi edible coating suhu $\pm 8^{\circ} \mathrm{C}$ dengan perbedaan masa simpan selama 1 hari, 4, 10, 12, 14, dan 21 hari mempengaruhi bilangan peroksida, angka iod, aktivitas antioksidan, jumlah bakteri, S. aureus, E. coli, dan Salmonella sp. Kemampuan bahan kasein dan kitosan pada edible coating ayam memiliki kemampuan stabil selama 110 hari. Selanjutnya perlu dilakukan upaya pretreatment sebelum dilakukan pengaplikasian edible coating pada bahan makanan.

\section{UCAPAN TERIMA KASIH}

Penulis berterimakasih kepada LPPM Universitas Brawijaya atas Hibah Penelitian Pemula Tahun Ajaran 2019/2020.

\section{DAFTAR PUSTAKA}

[1]. Abdellah, A.M., Khogali El Nour Ahmed Ishag., H.M. Omer. (2012). Assessing The Sudanese Standards and Guidelines of Edible Oils: A Case
Study of Sunflower Oil, AmericanEurasian J. Agric. and Environ. Sci. 12 (5): 682-688.

[2]. Andayani, R., Lisawati, Y., dan Maimunah. (2008). Penentuan Aktivitas Antioksidan, Kadar Fenolat Total dan Likopen Pada Buah Tomat (Solanum Lycopersicum L). Jurnal Sains dan Teknologi Farmasi, Vol. 13, No. 1, Fakultas Farmasi, Universitas Andalas, Padang.

[3]. Apriliyani, M.W., P.P Rahayu, R.D Andriani, A Manab, ME Sawitri, DT Utama. (2020). Characteristics of Casein-Chitosan Edible Coating and Its Preservative Effect in Meat during Accelerated Storage. IOP Conference Series: Earth and Environmental Science 478 (1), 012060.

[4]. Apriyantono, A., Fardiaz, D., Puspitasari, N. L., Sedadarnawati dan Budiyanto, S. (1989). Petunjuk Laboratorium Analisa Pangan. Pusat Antar Universitas Pangan dan Gizi. Instutut Pertanian Bogor. Bogor.

[5]. Badan Standardisasi Nasional. (2013). Standar Nasional Indonesia Minyak Goreng. SNI 37741:2013 ICS 67.200.10.

[6]. Bourtoom, T. (2008). Edible Films and Coating: Characteristic and Properties. International Food Research Journal. 15(3):237-248.

[7]. Duan, J., Jiang, Y., Cherian, G., and Zhao, Y. (2010). Effect of combined chitosan-krill oil coating and modified atmosphere packaging on the storability of cold-stored lingcod (Ophiodon elongates) fillets. Food Chemistry, 122 (2010): 1035-1042.

[8]. Fjell C D, Hiss J A, Hancock R E and Schneider G. (2012). Designing antimicrobial peptides: form follows function Nat. Rev. Drug Discov. 11 (1): 3751.

[9]. García, M., Yanisleidi, S. and Alicia, C. (2014). Food Science and Nutrition REGULAR ARTICLE Development of a mayonnaise with chitosan as natural antioxidant. Emir. J. Food Agric. 26 (10): 835-843 doi: 10.9755/ejfa.v26i10.17867 http://www.ejfa.info/ 835

[10]. Gheisari, H.R. (2011). Correlation Between Acid, TBA, Peroxide and Iodine Values, Catalase and Glutathione Peroxide Activities of Chicken, Cattle and Camel Meat DuringRefrigerated Storage. Veterinary World, 4(4): 153-157. 
[11]. Günlü, A. and Koyun, E. (2013). Effects of Vacuum Packaging and Wrapping with Chitosan-Based Edible Film on the Extension of the Shelf Life of Sea Bass (Dicentrarchus labrax) Fillets in Cold Storage $\left(4{ }^{\circ} \mathrm{C}\right)$. Food Bioprocess Technol, 6:1713-1719. DOI 10.1007/s11947-012-0833-6

[12]. Gunawan., Triatmo, M., dan Rahayu, A. (2003). Analisis Pangan: Penentuan Angka Peroksida dan Asam Lemak Bebas Pada Minyak Kedelai dengan Variasi Menggoreng. JSKA VI (3).

[13]. Hajrawati dkk. (2016). Kualitas Fisik, Mikrobiologis Dan Organoleptik Daging Ayam Broiler Pada Pasar Tradisional Dibogor. Jurnal Ilmu Produksi Dan Teknologi Hasil Peternakan 4(3):- .

[14]. Julianto, G.E., Ustadi, dan Husni, A. (2011). Karakterisasi Edible Film dari Gelatin Kulit Nila Merah dengan Penambahan Plasticizer Sorbitol dan Asam Palmitat. Jurnal Perikanan (Journal of Fisheries Sciences). 13(1): 27-34.

[15]. Ketaren, S. (2005). Minyak dan Lemak Pangan. Penerbit Universitas Indonesia: Jakarta.

[16]. Khare, A.K., R. J. J. Abraham, V. A. Rao, R. N. Babu, and W. Ruban. (2016). Effect of Chitosan Coating Enriched with Cinnamon Oil (Cinnamomun zeylanicum) on Storage Stability of Refrigerated Chicken Meat Nuggets. Journal of Animal Research 6 (2): 181-194.

[17]. López-Caballero, M. E., Gómez-Guillén, M. C., Pérez-Mateos, M., \& Montero, P. (2005). A chitosan-gelatin blend as a coating for fish patties. Food Hydrocolloids, 19, 303-311.

[18]. Lopez '-Exposito ', I., Ana Q, Lourdes A., and Isidra R. (2007). Casein hydrolysates as a source of antimicrobial, antioxidant and antihypertensive peptides. Lait 87: 241-249. http://dx.doi.org/10.1051/lait:2007019

[19]. Maruddin, F., Ako, A., Hajrawati, dan Taufik, M. 2016. Pengaruh Kombinasi Whey dan Kasein Sebagai Bahan Dasar Pembuatan Edible Film terhadap Karakteristik Edible Film. Seminar Nasional Peternakan.

[20]. Mohan, C. O., Ravishankar, C. N., Lalitha, K. V., \& Srinivasa Gopal, T. K. (2012). Effect of chitosan edible coating on the quality of double filleted Indian oil sardine (Sardinella longiceps) during chilled storage. Food Hydrocolloids, 26, 167-174

[21]. Moreira, M., Pereda, M., Marcovich, N., Roura, S. (2011). Antimicrobial Effectiveness of Bioactive Packaging Materials from Edible Chitosan and Casein Polymers. J. Food Sci 76: 54-63.

[22]. Nouri, A., Yaraki, M. T., Ghorbanpour, M., Agarwal, S., \& Gupta, V. K. (2017). Enhanced antibacterial effect of chitosan film using Montmorillonite/CuO nanocomposite. International Journal of Biological Macromolecules, 109: 1219-1231. https://doi.org/ 10.1016/j.ijbiomac.2017.11.119.

[23]. Nowzari, F., B. Shabanpour, and S. M. Ojagh, (2013). Comparison of chitosan-gelatin composite and bilayer coating and film effect on the quality of refrigerated rainbow trout. Food Chemistry 141 (3): 1667-1672.

[24]. Rajaram, D., and Rasool, A.N. (2010). Antioxidant properties of protein hydrolysates obtained from marine fishes Lepturacanthus savala and Sphyraena barracuda International Journal of Biotechnology \& Biochemistry, 6, (3): 435+. Gale Academic OneFile.

[25]. Rauf, Rusdin. (2015). Kimia Pangan. Andi: Yogyakarta.

[26]. Sartika, D., Susilawati, dan G. Arfani. 2016. Identifikasi Cemaran Salmonella sp. pada Ayam Potong dengan Metode Kuantifikasi di Tiga Pasar Tradisional dan Dua Pasar Modern di Kota Bandar Lampung. Jurnal Teknologi Industri \& Hasil Pertanian 21 (2): 89-96.

[27]. Sathivel, S. (2005). Chitosan and protein coatings affect yield, moisture loss, and lipid oxidation of pink salmon (Oncorhynchus gorbuscha) fillets during frozen storage. Journal of Food science, 70: 455-459.

[28]. Turkoglu, H., Z.G. Ceylan and K. S. Dayisoylu. (2003). The Microbiological and Chemical Quality of Orgu Cheese Produced in Turkey. Pakistan journal of Nutrition. 2 (2): 92-94.

[29]. Verlee, A., Mincke, S., \& Stevens, C. V. (2017). Recent developments in antibacterial and antifungal chitosan and its derivatives. Carbohydrate Polymers, 164, 268-283. https:// doi.org/10.1016/j.carbpol.2017.02.001. 